\title{
THE INFLUENCE OF FIRST LANGUAGE ON THE PRONUNCIATION OF SECOND LANGUAGE (A CASE STUDY OF THE MEMBERS OF ENGLISH CLUB AT MTS SALAFIYAH SYAFIIYAH MUMBULSARI JEMBER)
}

\author{
Nailul Authar \\ Universitas Nahdlatul Ulama Surabaya \\ e-mail: nailulauthar@unusa.ac.id
}

\begin{abstract}
The first language will always influence the second language acquisition. The influences involve all parts of language learning such language skills (speaking, reading, listening, and writing) and language components (vocabulary, grammar, and pronunciation). In particular, this current study focuses on investigating the influence of first language on the pronunciation of second language. It is found that there is a negative transfer got by most of the members of English club at MTS Salafiyah Syafiiyah Mumbulsari Jember. The respondents make more mistakes or errors because of the interference of their L1 to the L2 as a result of negative transfer. This paper is divided into seven parts. Those are introduction, the definition of LI and L2, the definition and features of pronunciation, research design, and pronunciation test given to the respondent, result, discussion, and conclusion.
\end{abstract}

Keywords: first language, second language, pronunciation, transfer process

\begin{abstract}
Abstrak: Bahasa pertama akan selalu memengarubi perolehan bahasa kedua. Pengaruh tersebut melibatkan semua bagian bahasa yang mempelajari kemampuan bahasa tersebut (berbicara, membaca, mendengar, dan menulis) dan komponen bahasa (kosa kata, tata bahasa, dan pengucapan). Secara khusus, penelitian ini berfokus untuk menganalisis pengaruh bahasa pertama pada pengucapan bahasa kedua. Ditemukan bahwa ada transfer negatif yang didapat sebagian besar anggota klub Inggris di MTS Salafiyah Syafiiyah Mumbulsari Jember. Responden membuat lebih banyak kesalahan, karena a danya gangguan L1 mereka terhadap L2 akibat transfer negatif. Jurnal ini terbagi menjadi tujuh bagian. Itu adalah pendahuluan, definisi LI dan L2, definisi dan fitur pengucapan, desain penelitian, uji pengucapan yang diberikan kepada responden, hasil, diskusi, dan kesimpulan.
\end{abstract}

Kata kunci: bahasa pertama, bahasa kedua, cara pengucapan, proses transfer

\section{Introduction}

Pronouncing Indonesian words is slightly different from pronouncing English words. Although there are 26 letters in the English alphabet, the sounds which may be produced are almost double that number (Gebhardt, 2010). It means that the way to pronounce the English words is not the same as what the reader reads from the written form. English language learn- ers in Indonesia often pronounce English words with Indonesian spelling when they speak English. For instance, they often pronounce "know [nəv]" with "[knəv]", "Might [mart]" with "[maig]". Besides, Indonesian words are pronounced without paying attention on certain stress because there is no stress in pronouncing Indonesian words. Otherwise, English words are pronounced with making stress in certain 
syllable. That is another common problem why Indonesian learners often feel difficult to pronounce the English words correctly.

In addition, Indonesian learners often pronounce English words by using the accent of L1. Long (1990)concludes that an L2 is usually spoken without accent if learning begins by the age of 6 years, with a foreign accent if learning begins after the age of 12 years, and with variable success between the ages of 6 and 12 years. On the other words, if the students learn English after the age of 12 years old it means that they pronounce English by using the accent of their mother tongue. Furthermore, when adults who typically have an accent, learn to pronounce or speak L2, their accent will sound as foreign accented (Ueyama, 2000). Therefore, people consider that the sound patterns or structures of the L1 influence the production of their L2.

The influence from the L1 is perceived in language transfer. It is transfer is a kind of influence from old knowledge to new knowledge (Zhanming, 2014). Besides, the main claim with regard to transfer is that the learning of task A will affect the following learning of task B (Gass and Selinker, 1994). While Lado (1957)previously states that individuals tend to transfer the forms and meanings, and the distribution of forms and meanings of their native language and culture to the foreign language and culture. There are two kinds of transfer that occurs in the process of learning L2, the first is learners make more mistakes or errors because of the interference of their L1 to the L2 as a result of negative transfer, and the second is learners have less or no errors in learning L2, as a result of positive transfer.

Hence, in this study, the researcher conduct a mini research dealing with the influence of $\mathrm{L} 1$ on the pronunciation of L2 by giving the students pronunciation test to investigate whether the transfer result is positive or negative.

\section{Definition of L1 and L2}

According to Gass and Selinker (1994) first language acquisition is the process a child learns his or her first language. While second language acquisition refers to the acquisition of any language after the acquisition of the mother tongue (Ellis, 1997). In addition, the process of learning another language after the native language has been learned is perceived as second language acquisition as well (Gass\&Selinker, 2008). Even the process acquiring the third, fourth, and fifth language are called SLA as well.

\section{The Definition and Features of Pronuncia- tion}

Pronunciation is how to pronounce words correctly. Zaremba (2010) explains that pronunciation refers to the correct way to emphasize syllables within a word. Incorrect pronunciation can also affect the meaning of words. Emphasizing the wrong syllables of words can also change the meaning of words. The nonnative speakers of English who speak English have to be very careful in pronouncing some utterances or he may create mispronunciations which lead to misunderstanding. In addition, the pronunciation system is unique because the written form is uttered differently from the spoken form. This is the reason why many people claim that the pronunciation of the English language is difficult.

The features of pronunciation consist of two sub-topics; those are phonemes and the aspects of pronunciation. 


\section{Phonemes}

Phonemes are different sounds within a language (Kelly, 2000). Although there are slight differences in how individuals articulate sounds, people can still describe accurately how each sound is produced. The meaning of the word can be changed or not when the speaker utters incorrectly. Because of that, the role of phonemes is important. For example, the word rat has the phonemes $/ \mathrm{r} x \mathrm{t} /$. If the middle phoneme is changed, it becomes /rot/rot, a different word. Yet, if $/ \mathrm{r} /$ is pronounced in a slightly different way, the word does not change and it is still understandable with the same meaning.

Kelly (2000) explains that there are two categories of the set of phoneme. Those are vowel sounds and consonant sounds.

\section{a. Vowel Sounds}

The vowels are produced in which the air stream can pass freely through and out of mouth (Kusuma, 1990:14). These sounds are made in which there is no hindrance to the flow of air as it passes from the larynx to the lips. Based on Kelly (2000:31-33) English has twelve pure vowels and divided to be close vowels, mid vowels, and open vowels. They are:

Close vowels: For close vowels the tongue is quite high in the mouth.

Examples:

1. [i:] - key /ki:/

2. [I] - sieve /siv/

3. [v] - book /bok/

4. [u:] - food /fu:d/

Mid vowels: For mid vowels the tongue is neither high nor low in the mouth.

Examples:

1. [e] - egg /eg/

2. [o:] - pour /po:(r)/

3. [3:] - shirt $/ \int 3: t /$

4. [ə] - paper/'peipə(r)/
Open vowels: For open vowels, the tongue is low in the mouth.

Examples:

1. [æ] - hat /hæt/

2. [p] $-\operatorname{dog} / \mathrm{dpg} /$

3. $[\Lambda]-$ front $/$ fr $\Lambda$ nt/

4. [a:] - far $/ f a:(r) /$

According to the tongue position, Kelly (2000) states that the English vowels can be put in a chart as follows:

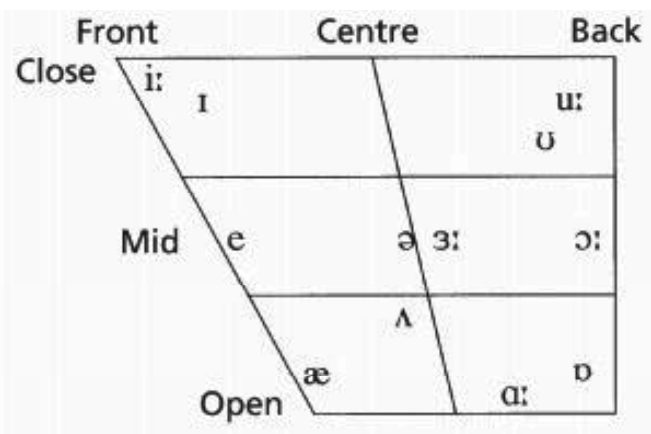

(Chart 2.1 Kelly, 2000:5)

Kelly (2000)states that vowel sounds are all voiced, and may be single such as (/e/, as in let), or a combination, involving a movement from one vowel sound to another such as (/eI/, as in late). Besides, Kusuma (1990:15) asserts that a diphthong is a sound made by gliding from one vowel position into another position. In other words, diphthong is a sound which consists of a movement or glide from one vowel to another. Kelly (2000:35-36) adds that there are eight diphthongs, as follows.

\section{Research Design}

Research designs are the speciûc procedures involved in the research process: data collection, data analysis, and report writing (Creswell, 2012:20). Previously, Creswell (2009: 22) defined research design as plans and the procedures for research that span the decisions from broad assumptions to detailed methods of data collection 
and analysis. This plan involves several decisions, which design, procedures of inquiry (called strategies), specific methods of data collection, analysis, and interpretation should be used to study a topic. Qualitative research in the term of a case study was used because this study tends to investigate the influence of L1 on the pronunciation of $\mathrm{L} 2$ by giving the students pronunciation test to investigate whether the transfer result is positive or negative.

A case study is a qualitative approach in which the researcher conducts an empirical investigation of a contemporary phenomenon within its natural context using multiple sources of evidence (Yin, 2011:307). Furthermore, Cohen et al. (2007:258) state that:

"Unlike the experimenter who manipulates variables to determine their causal significance or the surveyor who asks standardized questions of large, representative samples of individuals, the case study researcher typically observes the characteristics of an individual unit - a child, a clique, a class, a school or a community. The purpose of such observation is to probe deeply and to analyze intensively the multifarious phenomena that constitute the life cycle of the unit with a view to establishing generalizations about the wider population to which that unit belongs".

\section{Research Setting and Subject}

This mini research was conducted at MTS Salafiyah Syafiiyah Mumbulsari Jember. It is located at Jalan KH Agus Salim 1 Mumbulsari Jember East Java.This school is the oldest school in Mumbulsari which have a good English Club.

\section{Respondent}

The participants of the research are eligible units of population from which data would be collected. Creswell (2009:54) defines population as people who can answer the problem statements of the research. The participants of research must meet certain criteria in order to be included in a study. The criterions are specific to the objectives of qualitative analysis (Vanderstoep and Johnston, 2009:194). In this mini research, the participants who qualified to participate in this research are9 students. They belong to: 1) the students of English Club at MTS SalafiyahSyafiiyahMumbulsari, 2) they never go to the English Speaking country, (3) They have passed the test of Pronunciation in English Club, and (4) They have learned and used Indonesian since their childhood.

\section{Pronunciation Test Given to the Respon- dents}

Instruction: Read the words ONCE without reading the numbers!

\begin{tabular}{|c|l|c|l|}
\hline No. & \multicolumn{1}{|c|}{ Words } & No. & \multicolumn{1}{|c|}{ Words } \\
\hline 1 & Summer & 26 & Exchange \\
\hline 2 & Promises & 27 & Magical \\
\hline 3 & Silence & 28 & Fantasy \\
\hline 4 & Destination & 29 & Distraction \\
\hline 5 & Sharing & 30 & Complete \\
\hline 6 & Pushing & 31 & Solitary \\
\hline 7 & Thousand & 32 & Impossible \\
\hline 8 & Breathing & 33 & Afraid \\
\hline 9 & Anything & 34 & Believe \\
\hline 10 & Strangest & 35 & Perfect \\
\hline 11 & Cherish & 36 & Special \\
\hline 12 & Future & 37 & Reality \\
\hline 13 & Towel & 38 & Program \\
\hline 14 & Tower & 39 & Beginning \\
\hline 15 & Sour & 40 & Meaning \\
\hline 16 & Favorite & 41 & Edges \\
\hline 17 & Again & 42 & Winter \\
\hline 18 & Crazy & 43 & Angel \\
\hline 19 & Beside & 44 & Spinning \\
\hline 20 & Sunrise & 45 & Beautiful \\
\hline 21 & Alright & 46 & Watching \\
\hline 22 & Downtown & 47 & Closer \\
\hline 23 & Mountain & 48 & Outside \\
\hline 24 & Around & 49 & Children \\
\hline 25 & Arrange & 50 & Surrounded \\
\hline & & & \\
\hline
\end{tabular}


Nailul Authar, The Influence of First Language on the Pronunciation of Second Language (A Case Study of the Members of English Club at MTs Salafiyah Syafiiyah Mumbulsari Jember)

\section{Keys for Pronunciation Test (Post Test)}

1. Summer /'sımə(r)/

2. Promises /'promisis/

3. Silence /'sarləns/

4. Destination/destr'ner/n/

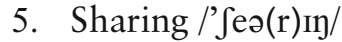

6. Pushing /'pufin/

7. Thousand /'Oauznd/

8. Breathing/bri:ðı/

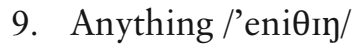

10. Strangest /'streindzes/

11. Cherish /'t $\int e r i g /$

12. Future /'fju:tfo(r)/

13. Towel /'tavəl/

14. Tower /'tavə(r)/

15. Sour /'savə(r)/

16. Favorite /'feivərit/

17. Again /ə'gen/

18. Crazy /'kreızi/

19. Beside/bı'sard/

20. Sunrise /'s $s$ nraiz/

21. Alright/o:l'rait/

22. Downtown/'daun'taon/

23. Mountain /'mauntən/

24. Around/a'raond/

25. Arrange /ə’reindz/

26. Exchange/Iks't $\int \mathrm{eInd} / \mathrm{s}$

27. Magical /'mædzıkl/

28. Fantasy /'færntəsi /

29. Distraction /dr'stræk $\int \mathrm{n} /$

30. Complete/kəm'pli:t/

31. Solitary /'splatri/

32. impossible/Im'ppsabl/

33. afraid/o'freId/

34. believe /br'li:v/

35. perfect /'p3:frkt/

36. special /'spef1/

37. reality/ri'æləti/

38. program /'provgræm/

39. beginning /br'ginı/

40. meaning/'mi:nı/

41. edges /'edzes/

42. winter/'winta(r)/

43. angel /'emdzl//

44. spinning/'spinin/

45. beautiful/'bju:tifl/

46. watching /'wot $\int \mathrm{In} /$

47. Closer /'kləusə(r)/

48. outside /,aut'sard/

49. children /'t fildrən/

50. surrounded /sə'raundid/

\section{Table of Item Distribution}

\begin{tabular}{|c|c|c|}
\hline \multirow[t]{5}{*}{ Vowels } & i: & $\begin{array}{l}\text { Breathing /bri:ðıy/ } \\
\text { believe /bı'li:v/ } \\
\text { meaning /'mi:nı/ } \\
\text { Complete /kəm'pli:t/ }\end{array}$ \\
\hline & I & $\begin{array}{l}\text { spinning /'spının/ } \\
\text { beginning /bı'ginı/ } \\
\text { perfect /'p3:frkt/ } \\
\text { impossible /Im'ppsəbl/ }\end{array}$ \\
\hline & כ & $\begin{array}{l}\text { winter /'wintə(r)/ } \\
\text { Solitary /'splatri/ } \\
\text { Again /ə'gen/ }\end{array}$ \\
\hline & $\mathrm{u}:$ & $\begin{array}{l}\text { beautiful/'bju:ttfl/ } \\
\text { Future /'fju:t } \mathrm{t} \partial(\mathrm{r}) /\end{array}$ \\
\hline & $\ddot{x}$ & $\begin{array}{l}\text { Fantasy /'fæntəsi / } \\
\text { Distraction /di'stræk/n/ } \\
\text { reality/ri'æləti/ }\end{array}$ \\
\hline \multirow[t]{4}{*}{ Diphthongs } & eI & $\begin{array}{l}\text { Crazy /'kreızi/ } \\
\text { Favorite /'feivorit/ } \\
\text { afraid /ə'fresd/ }\end{array}$ \\
\hline & วठ & $\begin{array}{l}\text { Closer /'kləusə(r)/ } \\
\text { program /'prəogræm/ }\end{array}$ \\
\hline & aI & $\begin{array}{l}\text { Beside /br'sard/ } \\
\text { Sunrise /'s nnraiz/ } \\
\text { Alright /o:l'rart/ }\end{array}$ \\
\hline & av & $\begin{array}{l}\text { surrounded /sə'raundid/ } \\
\text { outside /,aut'sard/ } \\
\text { Around /ə'raond/ } \\
\text { Mountain /'maontən/ } \\
\text { Downtown /'daun'taon/ }\end{array}$ \\
\hline Triphthong & ауә & $\begin{array}{l}\text { Towel /'tavəl/ } \\
\text { Tower /'tavə(r)/ } \\
\text { Sour /'savə(r)/ }\end{array}$ \\
\hline \multirow[t]{5}{*}{ Consonant } & $s$ & $\begin{array}{l}\text { Summer /'s } \mathrm{mo} ə(\mathrm{r}) / \\
\text { Promises /'promisis/ } \\
\text { Silence /'sarləns/ }\end{array}$ \\
\hline & $\int$ & $\begin{array}{l}\text { Destination /destı'neIfn/ } \\
\text { Sharing /'Jeə(r)In/ } \\
\text { Pushing /'pufin/ } \\
\text { special /'spefl/ }\end{array}$ \\
\hline & $d_{3}$ & $\begin{array}{l}\text { Strangest /'streindzes/ } \\
\text { Magical /'mædzılk1/ } \\
\text { edges /'edzes/ } \\
\text { angel /'eındzl/ } \\
\text { Arrange /a'reindz/ }\end{array}$ \\
\hline & ts & 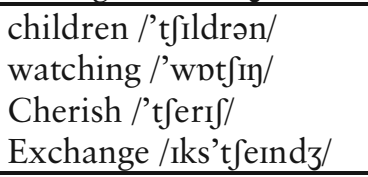 \\
\hline & $\theta$ & 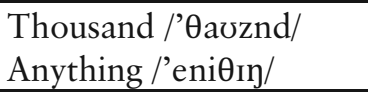 \\
\hline
\end{tabular}


The Result of Mini Research

The Score of Pronunciation Test

\begin{tabular}{|c|c|c|c|c|c|c|c|c|c|c|}
\hline No. & English Words & 1 & 2 & 3 & 4 & 5 & 6 & 7 & 8 & 9 \\
\hline 1 & Summer /'s məo(r)/ & 2 & 2 & 2 & 2 & 2 & 2 & 2 & 2 & 2 \\
\hline 2 & Promises /'promisis/ & 0 & 1 & 0 & 2 & 0 & 0 & 0 & 0 & 0 \\
\hline 3 & Silence /'sarləns/ & 2 & 2 & 2 & 2 & 2 & 2 & 0 & 2 & 2 \\
\hline 4 & Destination /destr'neIfn/ & 2 & 2 & 2 & 1 & 2 & 2 & 2 & 2 & 1 \\
\hline 5 & Sharing /'Jeə(r)rn/ & 0 & 2 & 2 & 1 & 2 & 2 & 2 & 2 & 2 \\
\hline 6 & Pushing /'pufin/ & 0 & 2 & 2 & 2 & 0 & 2 & 2 & 2 & 2 \\
\hline 7 & Thousand /' $\theta$ aoznd/ & 2 & 2 & 2 & 2 & 2 & 2 & 2 & 0 & 2 \\
\hline 8 & Breathing /bri:ðın/ & 2 & 2 & 2 & 1 & 2 & 2 & 2 & 2 & 2 \\
\hline 9 & 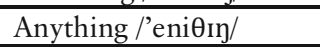 & 2 & 0 & 2 & 2 & 2 & 2 & 2 & 0 & 2 \\
\hline 10 & Strangest /'streIndzes/ & 2 & 2 & 0 & 0 & 2 & 2 & 0 & 2 & 0 \\
\hline 11 & Cherish /'teerif/ & 0 & 2 & 2 & 2 & 0 & 2 & 2 & 2 & 2 \\
\hline 12 & Future /'fju:t $\int \partial(r) /$ & 2 & 0 & 2 & 2 & 2 & 2 & 2 & 2 & 2 \\
\hline 13 & Towel /'tauəl/ & 0 & 2 & 2 & 2 & 2 & 2 & 2 & 0 & 2 \\
\hline 14 & Tower /'tave(r)/ & 0 & 2 & 2 & 1 & 2 & 2 & 2 & 0 & 2 \\
\hline 15 & Sour /'savo(r)/ & 0 & 2 & 0 & 0 & 0 & 2 & 0 & 0 & 2 \\
\hline 16 & Favorite /'feivərit/ & 2 & 2 & 0 & 2 & 0 & 0 & 2 & 2 & 0 \\
\hline 17 & Again /a'gen/ & 2 & 2 & 1 & 2 & 2 & 1 & 2 & 2 & 2 \\
\hline 18 & Crazy /'kreızi/ & 2 & 2 & 2 & 2 & 0 & 2 & 2 & 2 & 2 \\
\hline 19 & Beside /bı'said/ & 2 & 2 & 1 & 2 & 2 & 1 & 2 & 2 & 0 \\
\hline 20 & Sunrise /'sınraiz/ & 2 & 2 & 2 & 1 & 2 & 2 & 2 & 2 & 2 \\
\hline 21 & Alright /o:l'rait/ & 2 & 2 & 1 & 2 & 2 & 0 & 2 & 1 & 2 \\
\hline 22 & Downtown /'daun'taon/ & 2 & 2 & 2 & 2 & 2 & 0 & 2 & 2 & 2 \\
\hline 23 & Mountain /'mauntən/ & 0 & 0 & 0 & 1 & 0 & 0 & 2 & 0 & 0 \\
\hline 24 & Around /a'raond/ & 2 & 2 & 2 & 2 & 2 & 1 & 2 & 2 & 2 \\
\hline 25 & Arrange /o'remdz/ & 2 & 2 & 2 & 2 & 2 & 1 & 2 & 0 & 0 \\
\hline 26 & 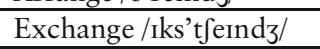 & 1 & 2 & 1 & 1 & 0 & 1 & 1 & 1 & 0 \\
\hline 27 & Magical /'mæd3ıkl/ & 2 & 2 & 2 & 1 & 2 & 2 & 2 & 2 & 2 \\
\hline 28 & Fantasy /'fæntəsi / & 2 & 0 & 2 & 1 & 0 & 2 & 2 & 2 & 0 \\
\hline 29 & Distraction /dı'strækfn/ & 2 & 2 & 2 & 1 & 1 & 2 & 2 & 0 & 2 \\
\hline 30 & Complete/kəm'pli:t/ & 0 & 2 & 0 & 2 & 0 & 0 & 2 & 0 & 0 \\
\hline 31 & Solitary /'solatri/ & 0 & 0 & 0 & 0 & 0 & 0 & 0 & 0 & 0 \\
\hline 32 & impossible /Im'ppsəbl/ & 2 & 0 & 0 & 2 & 0 & 2 & 2 & 0 & 0 \\
\hline 33 & afraid /ə'freid/ & 2 & 2 & 2 & 2 & 2 & 1 & 2 & 2 & 2 \\
\hline 34 & believe /br'li:v/ & 2 & 2 & 2 & 2 & 2 & 1 & 2 & 2 & 2 \\
\hline 35 & perfect /'ps:fikt/ & 0 & 0 & 2 & 0 & 0 & 0 & 2 & 0 & 0 \\
\hline 36 & special/'spef1/ & 0 & 0 & 0 & 1 & 2 & 2 & 0 & 0 & 0 \\
\hline 37 & reality/ri’æləti/ & 2 & 2 & 2 & 2 & 0 & 0 & 0 & 2 & 0 \\
\hline 38 & program /'prəugræm/ & 2 & 2 & 2 & 1 & 2 & 0 & 2 & 2 & 2 \\
\hline 39 & beginning /bi'gını// & 0 & 1 & 2 & 1 & 1 & 2 & 1 & 1 & 2 \\
\hline 40 & meaning/'mi:nıy/ & 2 & 2 & 2 & 1 & 2 & 2 & 2 & 2 & 2 \\
\hline 41 & edges /'edzes/ & 2 & 0 & 0 & 2 & 1 & 0 & 2 & 2 & 2 \\
\hline 42 & winter /'wintə(r)/ & 2 & 2 & 0 & 1 & 0 & 2 & 2 & 2 & 2 \\
\hline 43 & angel /'eindzl/ & 0 & 0 & 0 & 1 & 0 & 0 & 0 & 0 & 2 \\
\hline 44 & spinning /'spınıy/ & 2 & 2 & 2 & 1 & 2 & 2 & 2 & 2 & 2 \\
\hline 45 & beautiful /'bju:tıfl/ & 2 & 2 & 2 & 1 & 2 & 2 & 2 & 2 & 2 \\
\hline 46 & watching /'wot $\int \mathrm{ry} /$ & 2 & 2 & 2 & 1 & 2 & 2 & 2 & 2 & 2 \\
\hline 47 & Closer /'kləusə(r)/ & 2 & 0 & 0 & 1 & 0 & 2 & 2 & 2 & 2 \\
\hline 48 & outside /,avt'said/ & 2 & 2 & 0 & 2 & 2 & 0 & 1 & 0 & 1 \\
\hline 49 & children /'tsildrən/ & 0 & 2 & 0 & 1 & 2 & 2 & 2 & 0 & 2 \\
\hline \multirow[t]{2}{*}{50} & surrounded /so'raundid/ & 2 & 0 & 2 & 2 & 2 & 0 & 2 & 0 & 0 \\
\hline & Total Score & 69 & 74 & 66 & 71 & 63 & 65 & 81 & 61 & 68 \\
\hline
\end{tabular}

Note: Point $2=$ correct pronunciation and stress

Point $1=$ wrong pronunciation and correct stress / correct pronunciation and wrong stress

Point $0=$ wrong pronunciation and wrong stress 
Nailul Authar, The Influence of First Language on the Pronunciation of Second Language (A Case Study of the Members of English Club at MTs Salafiyah Syafiiyah Mumbulsari Jember)

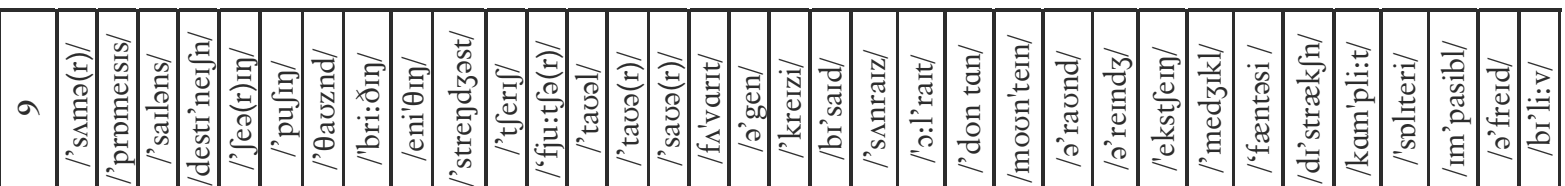

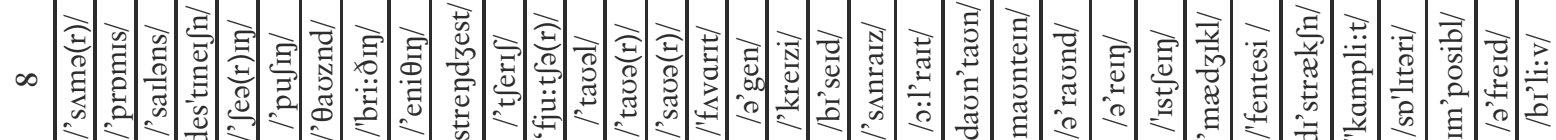

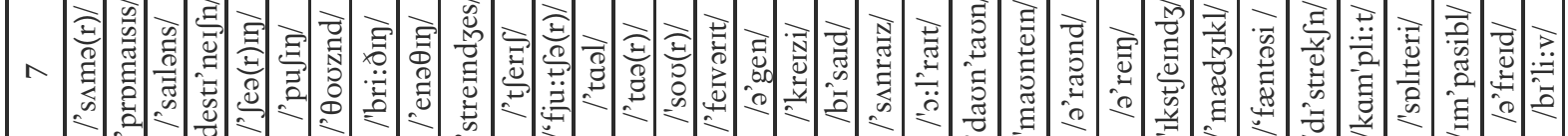

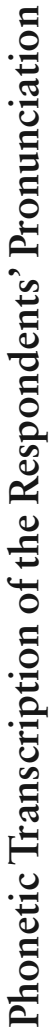

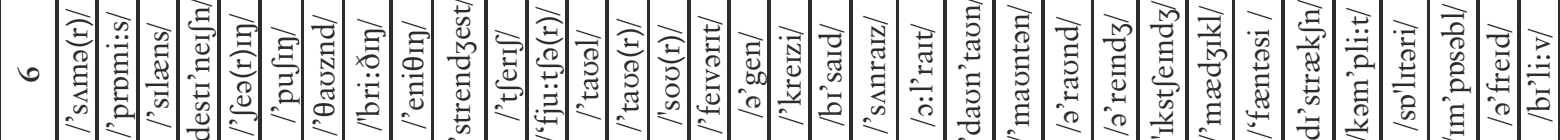

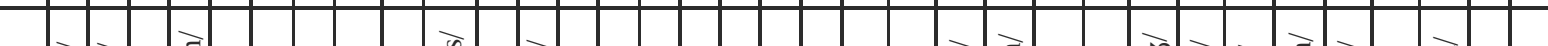

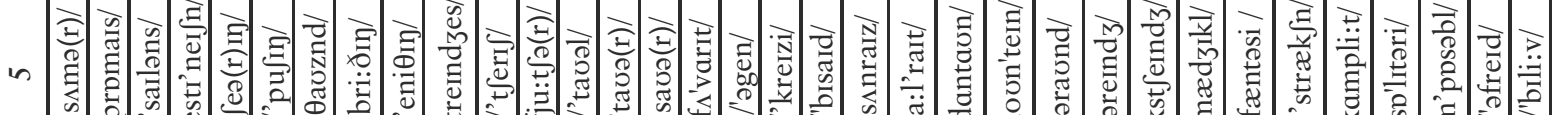

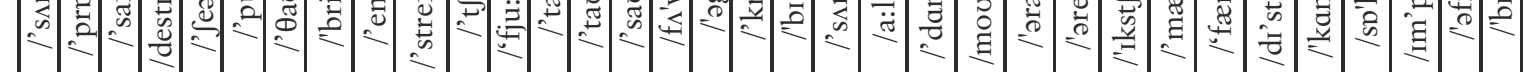

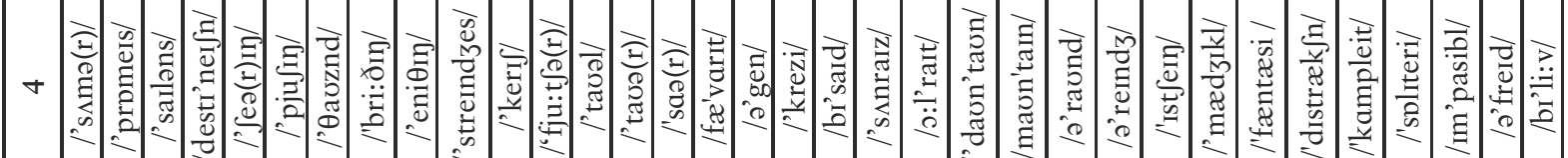

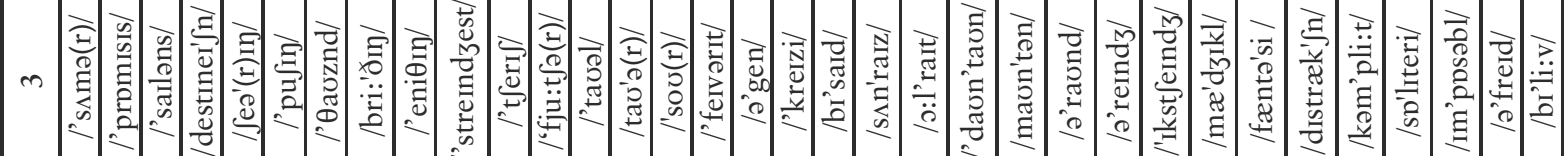

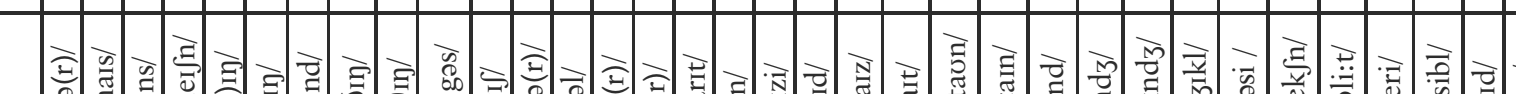

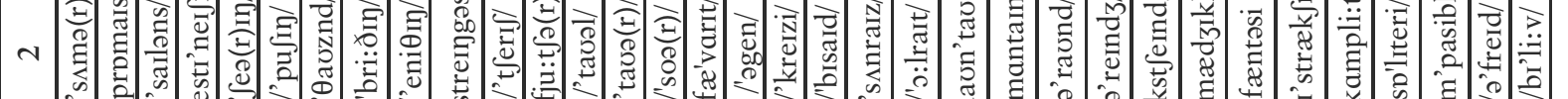

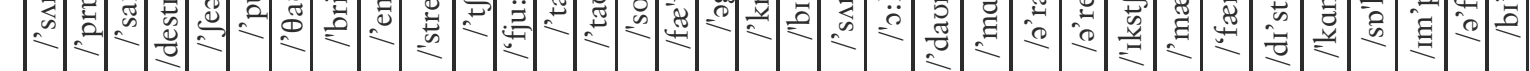

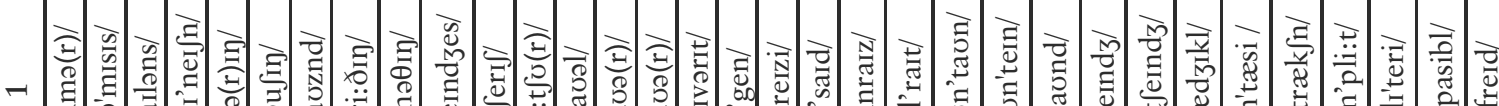

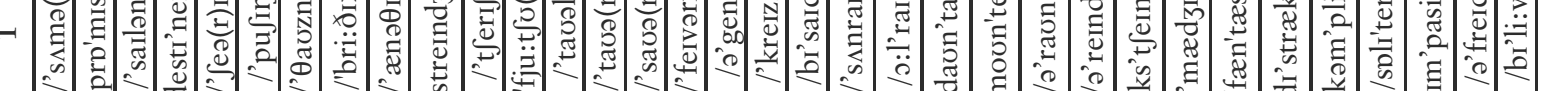

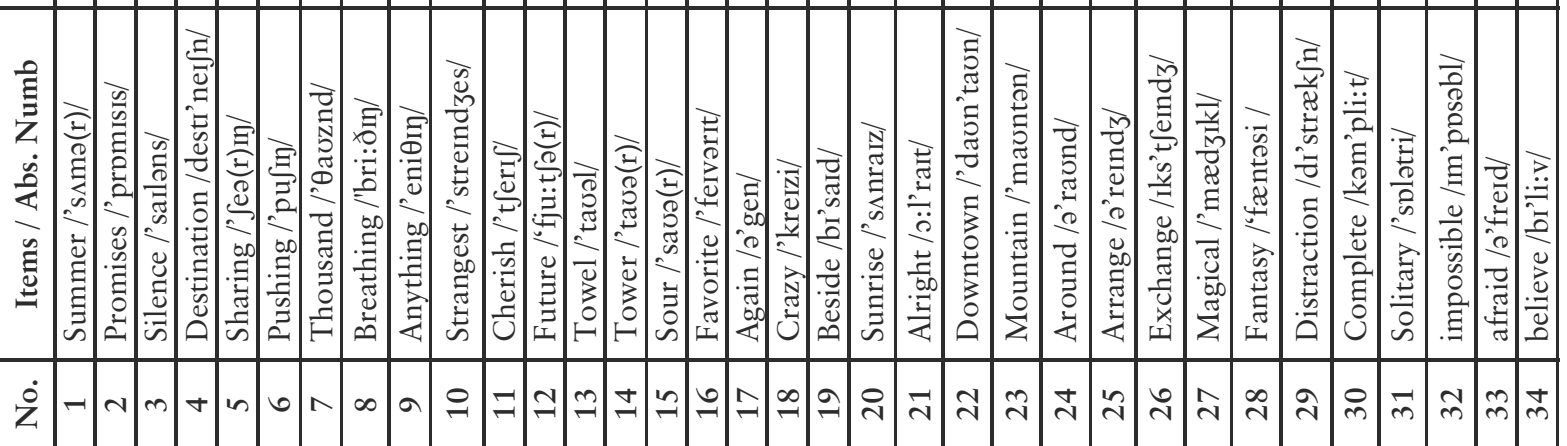




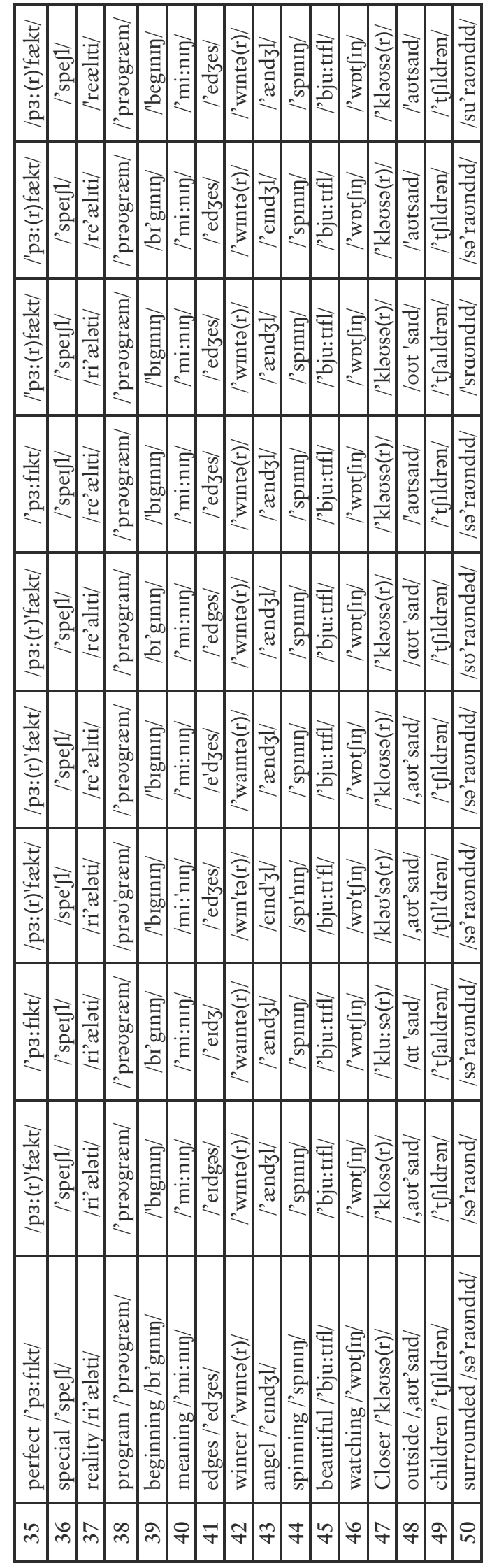

\section{Discussion}

Based on the result of the pronunciation test, there are only 3 respondents who get a good score (more than 70) on pronunciation test. The rest of them (6 respondents) get the score on the average 60 . It means that most of them face a difficulty in pronouncing the English words correctly.

The first problem faced by most of respondents is the word stress. Most of them make a wrong stress when they pronounce the English words. It happened because they do not have a word stress in Bahasa Indonesia as their first language. It makes them difficult to put a correct stress in pronouncing the English words.

The second problem is that most of the respondents get negative transfer. The way they pronounce the English words (especially on the English consonants and vowels) is incorrect. The researcher found that there are eight English consonants that are transferred incorrectly by the respondents. For instance, $[\mathrm{k}],[\mathrm{z}],[\mathrm{v}]$, $[\mathrm{S}],[\mathrm{T}],[\mathrm{D}],[\mathrm{n}]$ and $[\mathrm{d}]$. However, the English consonant sounds that pose major difficulties for the respondents are only for the sound $[\mathrm{z}]$, $[\mathrm{v}]$, and $[\mathrm{k}]$. The sound $[\mathrm{z}]$ in the word-final position is considered difficult since all of the respondents pronounce the sound incorrectly. In addition, unlike English which has the sound [z] in word-final position, Indonesian only has the sound $[\mathrm{z}]$ in word-initial and medial and never occurs in word-final, therefore they tend to produce $[\mathrm{s}]$ for $[\mathrm{z}]$. Furthermore, the nonexistence of the sound [v] in Indonesian sound system apparently influences the production of English sound [v]; as a result, the respondents produce $[\mathrm{f}]$ for $[\mathrm{v}]$. Since it is hard to hear the sound $[\mathrm{k}]$ in word-final of ask especially when it is produced in a fast speech; it is not pronounced by most of the respondents in this study. 
Furthermore, here are some words which are pronounced incorrectly by almost all respondents. It happened because English consonants or vowel is pronounced differently from bahasa Indonesia as their mother tongue. Here are the lists of those words:

\begin{tabular}{|c|l|l|l|}
\hline No. & $\begin{array}{c}\text { English } \\
\text { Words }\end{array}$ & $\begin{array}{c}\text { Correct } \\
\text { Pronunciation } \\
\text { and Stress }\end{array}$ & $\begin{array}{c}\text { Wrong } \\
\text { Pronunciation } \\
\text { and Wrong } \\
\text { Stress }\end{array}$ \\
\hline 1 & Promises & 1 respondent & 8 respondents \\
\hline 2 & Strangest & 4 respondents & 5 respondents \\
\hline 3 & Favorite & 4 respondents & 5 respondents \\
\hline 4 & Mountain & 3 respondents & 6 respondents \\
\hline 5 & Complete & 3 respondents & 6 respondents \\
\hline 6 & Solitary & 0 respondent & 9 respondents \\
\hline 7 & Impossible & 3 respondents & 6 respondents \\
\hline 8 & Angel & 1 respondent & 8 respondents \\
\hline 9 & Perfect & 2 respondents & 7 respondents \\
\hline
\end{tabular}

\section{Conclusion}

Most of respondents pronounce the English words incorrectly. From ten respondents, only 3 students who have high score (more than 70). The rest of them make a wrong stress and wrong pronunciation in pronouncing the English words. It can be concluded that most of the respondents got a negative transfer. As a result, most of them make more mistakes or errors because of the interference of their L1 to the L2 as a result of negative transfer.

\section{REFERENCES}

Cohen, Louis, Manion, Lawrence, \& Morrison, Keith. 2007. Research Methods in Education. Canada: Routledge.

Creswell, John W. 2009. Research Design: Qualitative, Quantitative and Mixed Method Approaches. United States: Sage Publication Inc.
Creswell, John W. 2012. Educational Research: Planning, Conducting and Evaluating Quantitative and Qualitative Research (Fourth ed.). Massachusetts: Pearson Education, Inc.

Ellis, Rod. 1997. The Study of Second Language Acquisition. Oxford: Oxford University Press.

Gass, Susan M., \& Selinker, Larry. 1994. Second Language Acquisition: An Introductory Course. Los Angeles: Lawrence Erlbaum Associates.

Gebhardt, Frederika. 2010. English Pronunciation.

Kelly, Gerald. 2000. How to Teach Pronunciation. Edinburgh Gate: Pearson Education Limited.

Lado, Robert. 1957. Linguistics across Cultures Applied Linguistics for Language Teachers. Ann Arbor: University of Michigan Press. Long, MH. 1990. Maturational Constraints on Language Development. Studies in Second Language Acquisition, No. 12, pp. 35.

Ueyama, M. 2000. Prosodic Transfer: An Acoustic Study of L2 English Vs. L2 Japanese. Unpublished doctoral dissertation Thesis, University of California, Los Angeles.

Vanderstoep, Scott W., \& Johnston, Deirdre D. 2009. Research Methods for Everyday Life. San Fransisco: John Wiley \& Sons, Inc.

Yin, Robert K. 2011. Qualitative Research from Start to Finish. New York: The Guilford Press.

Zaremba, Alan Jay. 2010. Crisis Communication: Theory and Practice. New York: M.E. Sharpe, Inc.

Zhanming, Wang. 2014. Review of the Influence of L1 in L2 Acquisition. Studies in Literature and Language, Vol. 9, No. 2, pp. 4, doi: 10.3968/5721. 
Education and Human Development Journal, Vol. 3, No. 1, April 2018 